\title{
Integrating Islamic Financing and Halal Industry: A Survey on Current Practices of the Selected Malaysian Authority Bodies
}

\author{
Nurul Aini Muhamed ${ }^{1}$, Nathasa Mazna Ramli ${ }^{1}$, Sumaiyah Abd Aziz ${ }^{1}$ \& Nor Asiah Yaakub ${ }^{1}$ \\ ${ }^{1}$ Faculty of Economics and Muamalat, Universiti Sains Islam Malaysia (USIM), Malaysia \\ Correspondence: Nurul Aini Muhamed, Faculty of Economics and Muamalat, Universiti Sains Islam Malaysia \\ (USIM), 71700 Nilai, Malaysia. Tel: 60-9-790-6383. E-mail: nurulaini@usim.edu.my
}

Received: May 28, 2013 Accepted: June 19, 2014 Online Published: August 20, 2014

doi:10.5539/ass.v10n17p120 URL: http://dx.doi.org/10.5539/ass.v10n17p120

This work is funded by the Universiti Sains Islam Malaysia Grant: PPP/FEM/HC/30/12912.

\begin{abstract}
Halal industry is a vast industry that consists of several sectors; ranging from food, pharmaceutical and cosmetic products, services (i.e. transportation and logistics) and, banking and finance. All these various sectors in the actual state of practices are currently positioned separately. This paper expands the proposal of integrating halal industries with the Islamic funds. Principally, these sectors should not be deemed separately as they are under the same umbrella of Shariah. The collaboration of the industry can lead to harmonious system that can support each other. In this case, the Islamic financial system through Islamic banking and capital market instruments will channel their long term funding to other Halal industry. As the start, it is important to look at the current practices of authority bodies in the sectors of Halal industry (except for Islamic banking and finance) and Islamic capital market. This outlook is prioritized given that the authority bodies will influence the behavior of the players. This paper focuses on Halal industry in Malaysia. Specifically, the main selected documents of the related authority bodies in this industry were assessed to grasp their approaches regarding Shariah compliance approval or Halal recognition. This will contribute to an initiative that can integrate this industry from the policy makers and supervisors' perspective. Finding shows that there are different angles of Halal aspects focused by these authority bodies, and there is a room for adjustment towards integration.
\end{abstract}

Keywords: halal industry, Islamic finance, integration of halal industry

\section{Introduction}

'Halal' is an all-encompassing term that refers to anything that is permitted and allowed from the Islamic Law. The opposite meaning of 'halal' is 'haram' which refers to anything that is prohibited by the decisive means (Laldin, 2006). By referring to halal industry, the term provides a very significant meaning of producing goods and services that can fulfill the halal requirements. In practice, the terms 'halal' and 'Shariah compliance' are used relatively varied according to the sectors and authority bodies even though they lead to the same meaning.

There is no doubt that halal industry is important for Muslims to ensure they can get halal goods and services. Halal industry grows very fast due to high demand from Muslim consumers around the world, affected by courage of religious concern. Malaysia aims to become the worldwide hub for both of the sectors. One of the results of the effort is that the Malaysian Halal Certification, which is designed to cater the halal goods sectors, have been named as the world's best example for halal food benchmarking by the United Nation in 1997 (Bohari, Wei Hin \& Fuad, 2013). Records show that the global halal industry is continuously growing; with the worldwide Halal food industry is valued at USD 667 billion and its annual growth at 16 per cent a year (DagangHalal.com, 2012). Consistently, the current Islamic finance asset is estimated at USD 1.3 trillion with the growth at 12 percent a year. Within this setting, Malaysia is acknowledged as the country which gives full effort to develop this industry, both for consumer goods and related services, and banking and financial sectors.

Concerns towards the disconnectedness of the different sectors in Halal industry, specifically consumer goods and related services with Islamic banking and finance, is critically discussed in the latest few limited writings in conference proceeding and magazines. Among the earlier academic and non-academic papers viewed on this issue are Abdalhamid Evans (2010), Ishak and Che Man (2011), Ahmad (2008) and Siddiqui (2013). Their main proposal is to unite the halal industry with Islamic banking and finance. In the other words, the capital from the 
Islamic banking and finance industry should be channeled to Halal industry to ensure the comprehensiveness of the compliance. The financial assistance in further could be interpreted in the variety forms of financial instruments including the equity, sukuk and Islamic banking products. This issue has also been discussed upon at several conferences and events such as at the Global Islamic Finance Forum 2012 and World Halal Forum 2013. However, not many studies have been done by looking at the practices of the halal industry per se to converge the different sectors in this industry.

Looking at these present circumstances, this paper endeavors to extend this agenda by looking at the current practices on the Halal certification or compliance which is an important part of halal industry._Specifically, it assesses the current practices of the authority bodies regarding 'halal certified' or 'shariah compliance' through their main documentation. The three main bodies are Jabatan Kemajuan Islam Malaysia (JAKIM), Securities Commission (SC) and Malaysia Department Standard (SIRIM). This paper is structured as follows; (i) introduction, (ii) Halal industry in Malaysia, (iii) agenda on Halal integration (iv) the authority bodies for Halal industry, (v) Authority bodies as governance mechanisms (vi) methodology (vii) comparison on documents and (ix) conclusion.

\section{Halal Industry in Malaysia: A Broad Perspective}

One of the landmarks for halal industry in Malaysia is the establishment of Lembaga Tabung Haji (Pilgrims Fund Board) in 1964 that functions as a saving institution for the pilgrimage purpose. This institution becomes the benchmark for the Islamic banking and finance in Malaysia and worldwide. Since then, full efforts have been made by the government to push the halal industry, both in banking and finance as well as consumer goods sectors. Among the main factors for government's and market participants' interests is the large opportunity of Halal industry and market demand for its products and services. In a broader perspective, the halal industry can be categorized into several sectors, specifically banking and finance, food and beverages, pharmaceutical and cosmetic products, logistic and tourism.

Malaysia undeniably is recognized as among the global leads for Islamic banking and finance due to its growth and comprehensive regulations. This sector started in 1983 with the formation of the first Islamic bank in Malaysia. From this significant beginning, the sector is expanded to the takaful and Islamic capital market (consist of several financial products such as equity, sukuk and funds). The progress in the Islamic banking industry is shown by the evidence that it is a second country that has the largest Islamic banking industry after Saudi Arabia in 2011 (Malaysian ICM, 2013). The 2012 data shows that Malaysia's sukuk outstanding size comprises 68 per cent of the total worldwide size, wherein the capital is channeled to financing different sectors in the capital market. In addition, the worldwide market value for consumer goods reached US\$680 billion (RM 2.17 trillion) in 2011, with more than US\$5 billion (RM 15 billion) came from Malaysia solely. This trend indicates vast opportunity that should be grabbed by Malaysian entrepreneurs (Utusan Malaysia, 2011).

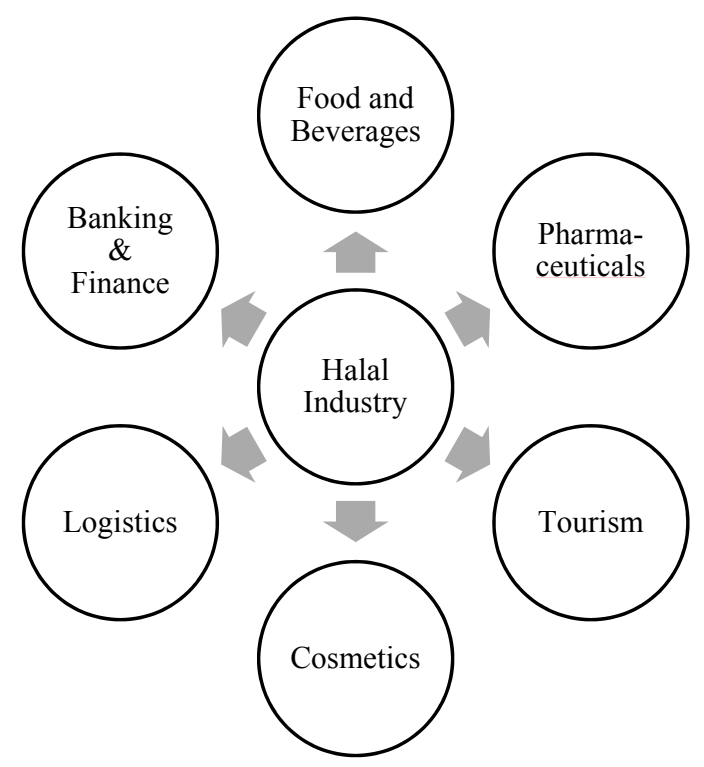

Figure 1. The selected sectors under the global halal industry

Source: Adapted from Halal Industry Development Corporation (2013) 
To ensure the integrity of the industry on consumer goods and related services sector, full support has been given by government to the related bodies that have been granted the authority to issue Halal Certificate and logo, and conduct the enforcement. Trade Description Act 2011 also covers part of halal and haram aspects related to monitoring the falsification of signage and images of Islam in the premises that are not granted Halal Certificate from JAKIM. The government's effort to strengthen the position of JAKIM Halal Certificate is also shown with the forbiddance of other private logos such as Islamic Food and Research Centre Asia, Persatuan Pegawai Agama Perak, IRANCA International, Halal Food Council S.E.A and Bahtera Lagenda Sdn Bhd. Since 2012, only Halal Certificate issued by JAKIM and State Religious Councils as well as international Halal certification that is approved by JAKIM, is officially recognized (Kosmo, 2012).

\section{The Authority Bodies for Halal Industry}

In general, the different sectors under the Halal industry are regulated by separated authority bodies. Similarly, the Islamic banking and financial sectors are also regulated by the different regulators, with the Bank Negara Malaysia controlling the Islamic banks and takaful providers and Securities Commission Malaysia (SC) controlling the Islamic capital market. These regulators work independently with different acts and regulations. To enhance the efficiency of the Islamic capital market, the SC issues list of Shariah compliance securities that can be used by investors as a guide for their investment. The SC method of equity assessment is based on two main aspects, namely the quantitative and qualitative screenings of the companies' annual financial reports (Malaysia International Islamic Finance Center, 2013). The lists are issued two times a year on May and November. Shariah Advisory Council is the highest body for compliance.

The main authority body for consumer goods and supportive services sectors is JAKIM with the support from the Department of State Religious Affairs (JAIN) / State Islamic Religious Council (MAIN). The main function of these authority bodies is to ensure the compliance of the applicants' (companies) products and services with Shariah requirements. JAKIM's document states the Halal Certification Panel is the highest body that is responsible for the approval. The Halal certification is granted once the companies fulfill the requirement, as indicated in the JAKIM's main document (ie. Halal Certification Procedures Manual). The certificate works as assurance towards halal compliance (Halal Industry Development Corporation, 2013). Differently from the Islamic banking and finance sectors, JAKIM's Halal certification is granted based on products/services that are being applied for certification rather than the whole products/services under the applicants' companies. The halal certification is valid for two years. However the status can be cancelled if the companies do not fulfill JAKIM's requirement after the certification.

SIRIM also supports JAKIM's operation by issuing standards that are read together with JAKIM's existing documents. Among those documents are MS 1500: 2009 (Halal Food - Production, Preparation, Handling and Storage - General Guidelines) and MS2200 (Islamic Consumer Goods - Part 1: Cosmetics and Personal care General Guidelines). SIRIM, a national organization that responsible for standardization and quality, is not accountable directly on halal industry in Malaysia as JAKIM. However, in addition to issue standards for other industry, SIRIM also issues its individual standard related to Islamic practices of organizations. The MS 1900: 2014 (Shariah-based Quality Management Systems-Requirement with Guidance (superseded the MS 1900:2005 Quality Management System - Requirement from Islamic Perspectives) is the standard that based on Islamic principles and governed by SIRIM. The standard is the basis for Shariah compliance certification that focuses on comprehensive compliance of individual companies with Islamic requirement. The method of certification is via the audit process. Differently from JAKIM procedure, its certification is granted based on management and overall practice of the companies, rather than by products.

\section{Agenda on Halal Integration}

Halal consumption and businesses are not just about halal ingredients and production process. It must cater all aspects of Halal and Haram in Islam. Islam should be practiced as the whole rather than taking only some parts of it. In that case, the halal goods should not be looked from the production part only but should be monitored as a whole process from getting the raw material until they are received by the consumers. Ishak and Che Man (2011) provide a discussion on the basis of the integration for this industry. Based on this argument, Islam is a comprehensive way of life where the guidance is given to lead humans. Halal compliance should cover broader aspects, not with the selective scope.

Then is it only a part of the Book that you believe in, and do you reject the rest? but what is the reward for those among you who behave like This but disgrace In This life?- and on the Day of Judgment They shall be consigned to the Most grievous penalty. for Allah is not unmindful of what ye do. (Al-Baqarah: 85) 
Ahmad (2008) in his analysis of Shariah literature linked this situation with pillars of contracts (contractors, recognized subject matters and, offer and acceptance), and elements that lead to the bound contract in the Islamic Transaction Law (Fiqh Muamalat). Recognized subjects here related to products and prices, and both must halal.

The industry however is criticized as does not unite and connect the halal industry with Islamic financing. The inconsistency has been highlighted by the World Halal Forum 2011 Director who stressed on the need to connect the two sectors - halal businesses and halal financing (Evans, 2010).The issue of inconsistency and gap related to Halal compliance process has been raised up but still gets less attention in practice. The data from Thomson Reuters shows that from 250 companies in the global halal industry and with a combined market capitalization of US\$ 132 billion, only 50 per cent are listed as halal compliance companies by the Accounting and Auditing Organization for Islamic Financial Institutions (AAOIFI). The data manifested that many companies do not utilize the Islamic financing even though they produce halal products and services (The Star, 2011). It is undeniable that there is a very strict process conducted in Malaysia, specifically by JAKIM, in granting halal status to applicants' production aspect (including source of raw materials, plant layout, logistic and process procedures). However, there is inconsistency when it comes to the financial aspect. Ahmad (2011) argues that there is no requirement for Halal compliance to be linked with Islamic financing. The main contemplation is the Shariah compliance should not be restricted to the narrow perspective of Halal ingredients and production process, but everything should be considered.

\section{Authority Bodies as External Governance Mechanism}

Corporate governance $(\mathrm{CG})$ is recognized as an approach to rule the behavior of the companies. Organization for Economic Co-operation and Development (OECD) provides a narrow perspective on CG, whereby the 'Corporate governance is about the way in which boards oversee the running of a company by its managers, and how board members are in turn accountable to the shareholders and the company (www.oecd.org, 2004). However, Turnbull (1997) puts CG in a larger context of including parties that can affect the behavior of the companies. Corporate governance is defined as 'all the influences affecting the institutional processes, including those for appointing the controllers and/or regulations, involved in organizing the production and sale of goods and services, (Turnbull, 1997, p. 181). This definition provides the basis of the importance of government's and the roles of the authority bodies.

In the companies that are focusing on the niche area of fulfilling the needs of specific customers, the elements of manufacturers' and providers' integrity become the most important elements. The certification and approval of the authority bodies in the Halal industry is a vital point of the customers' confidence (Mohamed et. al., 2008). The term Shariah Governance (SG) in Islamic banking and financial institutions is now becoming more significant and the center towards ensuring the compliance of companies with Shariah. The Islamic Financial Services Board (IFSB) defines SG as "the set of institutional and organisational arrangements through which an IIFS (Institutions Offering Islamic Financial Services) ensures that there is effective independent oversight of Shariah compliance" $(2009$, p. 2). The essence of the definition shows that an effective SG can drive the market participants to fulfill the needs of all stakeholders. Due to their importance, the government and the authority bodies should encourage and more aware of the process of the integration. This study examines on these documents of the authority bodies in order to identify whether both elements of financing and specific characteristic of products and organizations do appear in all three certification requirement.

\section{Methodology}

This study conducted a document analysis on materials that are related to the Halal certification process and procedures. The documents are the (i) Halal Certification Procedures Manual under JAKIM, (ii) MS 1900: 2014 (Shariah-based Quality Management Systems-Requirement with Guidance, under SIRIM, and (iii) Malaysian SC's Resolution of SC Shariah Advisory Council (under SC) and SC's new screening methodology. By doing this analysis, the specific gap between Islamic financing and Halal industries were identified. Furthermore, similarities between these bodies relating to these industries were also recognized.

\section{Comparison of Documents}

The three aspects that were compared in these three documents are (i) scope of the certification/compliance, (ii) general requirement for certification/compliance, and (iii) methods of assessment. The comparison is shown in Table 1. 
Table 1. Comparison on the practices from the selected documents

\begin{tabular}{|c|c|}
\hline Aspects & $\begin{array}{l}\text { Halal Certification } \\
\text { Procedures Manual }\end{array}$ \\
\hline $\begin{array}{l}\text { Scope of } \\
\text { certification/ } \\
\text { compliance }\end{array}$ & $\begin{array}{l}\text { - Guidelines } \\
\text { inspectors and for } \\
\text { manufacturers } \\
\text { - Providing the } \\
\text { requirements that must be } \\
\text { followed in obtaining Halal } \\
\text { certification. } \\
\text { (food and beverages, } \\
\text { pharmaceuticals, cosmetics) }\end{array}$ \\
\hline $\begin{array}{l}\text { General } \\
\text { Requirement } \\
\text { of } \\
\text { Evaluation }\end{array}$ & $\begin{array}{l}\text { - Each of company that } \\
\text { apply for the certification } \\
\text { shall ensure that the halal } \\
\text { certificate of source } \\
\text { ingredients are halal, and } \\
\text { select suppliers or } \\
\text { sub-contractors who supply } \\
\text { halal ingredients or have } \\
\text { halal certification. } \\
\text { - Every company is } \\
\text { required to have a minimum } \\
\text { of two employees who are } \\
\text { Muslim Malaysia citizen in } \\
\text { the kitchen / handling / } \\
\text { processing of food. } \\
\text { - Stresses on sanitary } \\
\text { equipment, transportation, } \\
\text { and production areas } \\
\text { (specific requirements } \\
\text { depend on type of } \\
\text { businesses) }\end{array}$ \\
\hline
\end{tabular}

Quality Management
System (MS 1900:2005)

Shariah Screening System (MS 1900:2005)

(Securities Commission Malaysia)

- Applicable to al organizations, regardless of type, size and product provided. (organizations) certification

(food and beverages, Each of company that

- The organization $\bullet$ All the public listed companies are screened based on specific
that apply for the developed criteria.
that apply for the developed criteria.

certification shall - Companies can be divided into two types according to their establish, document, activities, namely companies without mix income and companies with implement and maintain mix income (also involve in non-halal activities).

a quality management Companies that are not involved in stated items as their core system and continually activities:

improve its effectiveness (a)Financial services based on riba (interest);

in accordance with the (b) Gambling and gaming;

requirements of the (c) Manufacturing or selling of non-halal products or related products; standard.

(d) Conventional insurance;

(e) Entertainment activities that are non-permissible according to Shariah; - The quality (f) Manufacturing or selling of tobacco-based products or related system consists of : products;

- $\quad$ quality management

- management responsibility - resource management - $\quad$ product realization - measure, analysis improvement

(g) Stockbroking or share trading in Shariah non-compliant securities;

(h) Other activities deemed non-permissible according to Shariah.

For mix income companies, the benchmarks are*:

i) Business Activities

a. The $5 \%$ benchmark:

- conventional banking;

- $\quad$ conventional insurance;

- gambling;

- liquor and liquor-related activities; improvement and pork and pork-related activities; non-halal food and beverages; Shariah non-compliant entertainment; interest income from conventional accounts and instruments; tobacco and tobacco-related activities; and other activities deemed non-compliant according to Shariah.

b. The 20-percent benchmark:

- hotel and resort operations;

- share trading;

- $\quad$ stockbroking business;

- $\quad$ rental received from Shariah non-compliant activities; and

- other activities deemed non-compliant according to Shariah.

ii) Financial Ratios:

a) Cash over Total Assets

Cash will only include cash placed in conventional accounts and instruments, whereas cash placed in Islamic accounts and instruments will be excluded from the calculation

b) Debt over Total Assets

Debt will only include interest-bearing debt whereas Islamic debt/financing or sukuk will be excluded from the calculation.

Both ratios, which are intended to measure riba and riba-based elements within a company's balance sheet, must be lower than $33 \%$.

\begin{tabular}{|c|c|c|}
\hline $\begin{array}{l}\text { Method of } \\
\text { assessment }\end{array}$ & $\begin{array}{l}\text { Document and audit (not clearly stated) } \\
\text { on premises } \\
\text { Periodic monitoring } \\
\text { inspection on the premises } \\
\text { which have been given a } \\
\text { certificate / halal logo or use } \\
\text { the expression to be made by } \\
\text { at least two Islamic Affairs } \\
\text { Officers authorized. }\end{array}$ & $\begin{array}{l}\text { - Assessment on yearly financial statement of companies, survey } \\
\text { responses and feedback from management of companies. }\end{array}$ \\
\hline
\end{tabular}


Source: Halal Certification Procedures Manual, Resolution of the Securities Commission Shariah Advisory Council, SC (2013), MS 1900: 2014 (Shariah-based Quality Management Systems-Requirement with Guidance.

*SC's New Screening Methodology applies on November 2013

This study shows that the scopes of certification/compliance among these three documents are different, given that each of the documents focuses on the different angle of compliance. The JAKIM's focus in Halal Certification Procedures Manual is restricted to food and beverages, cosmetics and pharmaceutical products. On the other hand, SIRIM's MS 1900: 2014 (Shariah-based Quality Management Systems-Requirement with Guidance focuses on the management of business organization as a whole. The Securities Commission through the Resolution focuses on the evaluation of public listed companies in two aspects of the (i) business activities and (ii) financing sources.

The second aspect of comparison is on general requirement for certification/compliance. JAKIM via its documents has several requirements that should be fulfilled by the applicants to ensure their goods are certified. Among the requirements are matters related to ingredients, premises, equipment and logistics, and Muslim staff. Other specific requirements are depending on types of goods within the scope of general requirements. Based on evaluation, there is no requirement for the applicants to fulfill the Islamic principles of financing obligation.

The evaluation of SIRIM on audited companies consists of several aspects of quality management, management responsibility, resource management, product realization, and measure, analysis and improvement. The requirement on Islamic financing has been mentioned in the MS 1900: 2014 (Shariah-based Quality Management Systems-Requirement with Guidance as one part of the system. This is shown in one statement of the document as follows:

'The organisation should ensure that all sources of financing are Shariah compliant according to resolutions of Shariah Advisory Councils of Bank Negara Malaysia and Securities Commission Malaysia. In cases where no Shariah compliant resources are available, the organisation should consult its Shariah advisor or Shariah advisory body for decision' (MS 1900: 2014, p. 27).

Even though there is indication on financing based on Islamic principles in SIRIM's document, there is a tolerance in certain circumstances. In certain case, the requirement for Islamic financing may not affect the certification of some companies if there is no halal source is available.

Securities Commission (SC) on the other hand includes the requirement for the Islamic financing as part of their requirement to approve Halal Compliance Stock, parallel with other elements of prohibition. The main general activities which are prohibited and included under SC's assessment; the prohibition of riba' (usury), maysir (gambling), gharar (uncertainty) and alcohol and pork. On the fact that there are companies that have the mix activities, there are two screening methods that are introduced to overcome the issue, namely related to business activities and financial ratios.

The third evaluation is on the method of assessment. As indicated in its documents, the assessment method prior the approval decision under the JAKIM is through audit on documents and premises. The SC's evaluation on the companies is through document analysis of yearly financial statement of the companies, survey responses and the management feedback of the companies. Differently from JAKIM and SC, there is no clear indication of the evaluation method highlighted in the document prior granting the MS 1900: 2014 (Shariah-based Quality Management Systems-Requirement with Guidance certification.

Based on the evaluation, there is no substantial emphasis on the strict requirements on the source of capital based on specific Islamic parameters, except for SC. In this case, the SC's parameters are viewed as more stringent, in the way it also considers the aspect of business activities and financial ratios. There is an effort from the SIRIM to include the financing part using the Islamic principles, but yet at the minimum level. The results in actual fact support the previous claims such as by AbdalHamid Evans (2010) and Ahmad (2008). In that case, there might be a possibility that the companies that gain Halal certification for their products, but are not listed in the SC list.

\section{Conclusion}

This study attempts to expand the idea of bridging the gap between Islamic financing and halal industry to achieve the comprehensive halal compliance practices in Malaysia. Findings show that each of the authority bodies adopts different parameters and methods of assessment in regards to their Shariah compliant process. The SC parameters are considered as much more comprehensive compared to others. Since these three bodies issue the approval on Halal compliance from the different angles and procedures, there is a possibility of overlapping 
and untapped area due to different practices. It is argued that integrating the parameters are very significant and thus the collaboration among these authority bodies should be formed to strengthen the halal industry.

\section{References}

Bohari, A. M., Cheng, W. H., \& Fuad, N. (2013). An analysis on the competitiveness of halal food industry in Malaysia: an approach of SWOT and ICT strategy. Geografia: Malaysian Journal of Society and Space, $9(1)$.

Evans, A. (2010). Natural allies: Halal food and Islamic finance. Retrieved from http://halalmedia.my

Ahmad, K. A. (2008). Financing halal business: Islamic solutions for Muslim entrepreneurs in Malaysia. International Conference on Entrepreneurship.

DagangHalal.com. (2012). Halal food Middle East - advantages aplenty. Retrieved from http://www.daganghalal.com/HalalNews/HalalNewsDtl.aspx?id=2062

IFSB. (2009). Guiding principles on Shari ah governance systems for Institutions Offering Islamic Financial Services. Kuala Lumpur: Islamic Financial Services Board.

Ishak, F. I., \& Man, Y. C. (2011). Halal Economy: Proof from Al-Quran and As-Sunnah and Demands to Utilize It in Parallel. International Islamic Banking, Finance and Investment Conference.

Halal Industry Development Corporation. (2013). Industry sectors. Retrieved from http://www.hdcglobal.com/publisher/ bhi_industry_sectors

Jabatan Kemajuan Islam Malaysia. (2005). Manual Prosedur Pensijilan Halal Malaysia (MPPHM). Putrajaya: Jabatan Kemajuan Islam Malaysia.

Kosmo. (2012, January 1). 1,900 Premis jadi sasaran (p. 3).

Laldin, M. A. (2006). Islamic Law: An Introduction. Kuala Lumpur: International Islamic University Malaysia.

Malaysia International Islamic Financial Centre. (MIFC). (2013). Shariah screening methodology: Adopting a two-tier quantitative approach. Retrieved from http://www.mifc.com/

Malaysian Islamic Capital Market. (2013). Supporting further growth of Islamic finance. Kuala Lumpur: Securities Commission (Vol. A, No. 1).

Departments of Standard Malaysia. (2005). Quality Management Standard: Requirement from Islamic Perspectives.

Organisation for Economic Co-operation and Development (OECD). (2004). Improving business behaviour: Why we need corporate governance. Retrieved from http://oecd.org

Securities Commission. (2013). Malaysia. Senarai Sekuriti Patuh Syariah oleh Majlis Penasihat Syariah Suruhanjaya Sekuriti Malaysia. Retrieved from http://www.sc.com.my/wpcontent/uploads/eng/html/icm /sas/sc_syariahcompliant_310513.pdf

Md Zain, S. M. (2011). Is the halal issue in Malaysia resolved? Utusan Malaysia Online. Retrieved from http://ww2.utusan.com.my/

The Star Online. (2011). Halal industry should work with Islamic finance. Retrieved from http://biz.thestar.com.my

Turnbull, S. (1997). Corporate governance: Its scope, concerns and theories. Corporate Governance: An International Review, 5(4), 180. http://dx.doi.org/10.1111/1467-8683.00061

Mohamed, Z. A., Rezai, G., Shamsudin, M. N., \& Eddie Chiew, F. C. (2008). Halal logo and consumers' confidence: What are the important factors? Economic and Technology Management Review, 3, 37-45.

\section{Copyrights}

Copyright for this article is retained by the author(s), with first publication rights granted to the journal.

This is an open-access article distributed under the terms and conditions of the Creative Commons Attribution license (http://creativecommons.org/licenses/by/3.0/). 